\title{
EFFECTS OF GUANETHIDINE-INDUCED SYMPATHECTOMY ON CELL PROLIFERATION IN THE PROGENITIVE COMPARTMENTS OF THE NEONATAL MOUSE INCISOR
}

\author{
R. M. KLein ${ }^{1}$, D. J. Chiego JR ${ }^{2}$ and J. K. Aver Y ${ }^{2}$ \\ ${ }^{1}$ Department of Anatomy, University of Kansas Medical Center, College of Health \\ Sciences and Hospital, Kansas City, KS 66103, U.S.A. \\ ${ }^{2}$ Oral Histology Laboratory, Department of Oral Biology, The University of Michigan, \\ School of Dentistry, Ann Arbor, MI 48109, U.S.A.
}

\begin{abstract}
Summary--Treatment of mice with guanethidine sulphate every $48 \mathrm{~h}$ from birth until 14 days produced a 64.2 and 68.0 per cent reduction in perikarya of the superior cervical and coeliac ganglia, respectively, at 15 days after birth and 78.9 and 81.3 per cent at 30 days. The growth rate of mice between 21 and 30 days after birth was significantly reduced. At 15 and 30 days after birth, $\left[{ }^{3} \mathrm{H}\right]$-thymidine was injected into control and sympathectomized mice, and labelling indices for the inner enamel epithelium, outer enamel epithelium, stratum intermedium, stellate reticulum, odontoblasts, and pulp and periodontal ligament fibroblasts determined from autoradiographs. A statistically significant decline in labelling index was found in the inner enamel epithelium, stellate reticulum, and odontoblast cell populations at 30 days as compared to 15 days in controls. Sympathectomized mice demonstrated a significant decline in labelling index in the inner enamel epithelium, stratum intermedium, odontoblasts, and pulp fibroblasts at 30 days as compared to 15 days. The sympathetic nervous system, therefore, has only a minimal role in regulation in incisor eruption and cellular proliferation. The effect of sympathectomy on the stratum intermedium and stellate reticulum may be due to increased tissue pressure resulting from loss of vasoconstrictive sympathetic control.
\end{abstract}

\section{INTRODUCTION}

The continuously erupting rodent incisor, with its continually differentiating tooth formative cells, is an excellent model system for the analysis of the role of neural factors in the development of the teeth. The pattern of rodent incisor innervation (Ridehalgh and Stewart, 1938; Bernick, 1956) and the possible role of both sensory and sympathetic innervation on growth of the incisor has been studied by numerous investigators (Vieyra, 1927; King, 1936; Edwards and Kitchin, 1938; Taylor and Butcher, 1951; Miller, 1957; Rehak, 1963; Devoto, Arias and Perrotto, 1966). However, the role of the innervation in controlling growth remains equivocal despite these efforts. For example, inferior alveolar nerve (IAN) resection accelerates tooth eruption in the rat (Taylor and Butcher, 1951; Miller, 1957; Brown, Kupfer and Darlington, 1961; Rchak, 1963) and dog (King, 1936). King (1936) found that, in rabbits, IAN resection accelerated eruption for days 8-21 followed by a period of slight retardation (King, 1936), whereas no consistent effect was found after denervation in cats. Ronning and Isotupa (1973) and Isotupa and Ronning (1977) attributed the morphological alteration of the incisors following IAN resection, in the guinea pig, to local ischaemia and blood vessel damage during resection. However, contradictory data suggests that unless ischaemia is induced locally in the apical region of the tooth, there is little permanent effect on the monkey (Macaca mulatta) incisor (Butcher and Taylor, 1951); cutting the carotids in the neck produces no change in eruption rate of the rat incisor (Taylor and Butcher, 1951). Loss of sympathetic function after superior cervical ganglionectomy (SCG) has provided contradictory results: acceleration of eruption (King, 1936; Edwards and Kitchin, 1938) deceleration of eruption rate (Vieyra, 1927) or no effect on the rate of eruption (Taylor and Butcher, 1951).

Sympathetic nerve fibres may reach the incisor with the inferior alveolar nerve or in association with blood vessels (inferior alveolar or carotid artery), or by an alternate pathway to reach the pulp (Christensen, 1940), periodontal ligament or other cellular compartments. We used chemical sympathectomy with guanethidine-sulphate to destroy perikarya throughout the sympathetic chain, reducing the sympathetic influence on the developing tooth, irrespective of the possible neuronal pathways to the target organ.

\section{MATERIALS AND METHODS}

Timed-pregnant, female CF-1 mice (Carworth Division of Charles River Brceding Labs, Wilmington, Delaware) were received at least 10 days prior to parturition. They were fed water and Purina chow ad libitum and were maintained on a $12 \mathrm{~h}$ light-dark cycle, lights on 06:00 to 18:00 hours. Mouse pups were weaned at 28 days and kept under standard laboratory conditions. 


\section{Guanethidine treatment}

Beginning at birth and continuing every $48 \mathrm{~h}$ for 14 days, rats were injected subcutaneously with $20 \mu \mathrm{g} / \mathrm{g}$ body wt guanethidine sulphate (CIBA-Geigy, Summit, N.J.) in phosphate-buffered saline (PBS), pH 7.4. Only male mice were used, to avoid the possibility of sex difference. Eight injections were made to each animal. Control rats were litter-mates of experimental rats subjected to the same protocol, except that guanethidine was omitted from the PBS solution (vehiclecontrols).

\section{Assessment of sympathectomy}

Fifteen and 30-day-old mice were killed by an overdose of Metofane (Pitman-Moore Inc., Washington Crossing, N.J.) and the superior cervical and coeliac ganglia were removed and fixed in neutral-buffered formalin for $12 \mathrm{~h}$ before routine histological processing as $5 \mu \mathrm{m}$ paraffin-wax sections. Cell counts were performed as described by Barka, Chang and van der Noen (1972) through the maximal cross-sectional area of the ganglia, and compared for vehicle-control and guanethidine-treated mice.

\section{Analysis of cellular proliferation}

Twenty 15-day-old and twenty 30-day-old mice were used; 10 vehicle-controls and 10 guanethidinetreated mice in each age group. Mice were injected with $0.5 \mu \mathrm{Ci} / \mathrm{g}$ body wt $\left[{ }^{3} \mathrm{H}\right]$-thymidine $\left({ }^{3} \mathrm{H}-\mathrm{TdR}\right)$ with a specific activity of $6.7 \mathrm{Ci} / \mathrm{mmol}$ (New England Nuclear Co., Boston, Mass.) and killed $1 \mathrm{~h}$ later by an overdose of Metofane. The mandibles were dissected from the mouse skulls and split in half by cutting through the symphysis, fixed in neutral-buffered formalin, washed and demineralized in sodium citrateformic acid solution for 8 days in the 15-day-old mice and 28 days in the 30-day-old mice. After washing for $24 \mathrm{~h}$ in running tap water, the mandibles were dehydrated in alcohols, processed routinely for paraffinwax embedding, orientated in the sagittal plane and sectioned through the cervical loop region of the incisors. Five micrometre sections were cut and mounted on glass slides, dipped in NTB-2 Nuclear Track Emulsion (Eastman Kodak Co., Rochester, N.Y.) and stored in the dark at $4^{\circ} \mathrm{C}$ for 21 days. Slides were then developed in Kodak D-19 developer, washed briefly in distilled water, fixed in Kodak fixer, washed in running tap water and stained lightly with Harris haematoxylin and eosin. The autoradiographs had an average background of $1.0 \mathrm{grain} / \mathrm{cell}$. Unlabelled tissue sections from mice not injected with isotope were used as controls, and treated in an identical manner to the radiolabelled tissue sections from mice injected with ${ }^{3} \mathrm{H}-\mathrm{TdR}$. Vehicle-control slides were included in each box of autoradiographs processed for these experiments.

The percentage of ${ }^{3} \mathrm{H}$-TdR-labelled cells was determincd for vchiclc-control and guanethidine-treated mice of each of the two age groups. The presence of 4 silver grains over a cell nucleus was used to classify a cell as labelled. The proliferative compartments of the mouse incisor were defined as in experiments on the rat (Warshawaky and Smith, 1974) and mouse (Chiego, Klcin and Avery, 1981). Pre-secretory ameloblasts were defined as the layer of ameloblasts from the extreme basal end of the incisor through the region of ameloblasts facing the pulp and the basal $1 / 3$ of the ameloblasts facing the dentine (Warshawsky and Smith, 1974). All other cell types and progenitive zones were defined as described by Chiego et al. (1981).

Three thousand cells were counted per incisor (right and left) for each of the following cell types: inner enamel epithelium, outer enamel epithelium, stratum intermedium, stellate reticulum, odontoblasts, and pulp and periodontal ligament fibroblasts. Labelling index data for control and guanethidine-treated rats were compared using a $t$-test for paired observations.

\section{RESULTS}

\section{Effects of guanethidine treatment}

The effects of guanethidine administration on body weight is shown in Text Fig. 1. The equations of the lines are $y=0.572 x-0.468 \quad(r=0.963)$ and $y=0.449 x+0.442(r=0.960)$ for vehicle-control and guanethidine-treated mice. The slopes differ significantly with a $t$-test for comparison of slopes $(p<0.05)$. Growth between ages 24 and 30 days differed significantly $(p<0.05)$ when comparing weights of vehicle-control and guanethidine-treated mice with a $t$-test for paired observations.

\section{Assessment of sympathectomy}

Guanethidine treatment reduced the number of sympathetic ganglion cell bodies by 68.0 per cent (SCG) and 64.2 per cent (coeliac g) at 15 days and 78.0 per cent (SCG) and 81.3 per cent (coeliac g) by 30 days (Table 1). Plate 1, Fig. 2 illustrates morphological changes found typically in the superior cervical ganglia of guanethidine-treated mice (2B) compared to vehicle-controls $(2 \mathrm{~A})$.

\section{Effects of sympathectomy on labelling index $(L I)$}

Table 2 shows the results of counts of ${ }^{3} \mathrm{H}$-TdRlabelled cells for the cell types of the mouse incisor. Guanethidine sympathectomy produced a significant decrease in $\left[{ }^{3} \mathrm{H}\right]$-thymidine-labelling index only at 30 days of age in the stellate reticulum and stratum intermedium. However, there were differences in $\mathrm{LI}$ between 15 and 30 days of age in both vehicle-controls and sympathectomized mice. LI was decreased significantly $(p<0.001)$ in control mice at 30 days compared to 15 days in the inner enamel epithelium, stratum intermedium and odontoblasts. Sympathectomized rats showed a significant decline in labelling index in the inner enamel epithelium, stratum intermedium, odontoblasts and pulpal fibroblasts at 30 days compared to 15 days. The percentage reduction in LI varied between 11.7 and 73.7 per cent in controls and between 20.3 and 89.4 per cent in guanethidine-treated mice for the different cell types.

\section{DISCUSSION}

Administration of guanethidine sulphate in the early postnatal period alters body growth of mice and destroys perikarya in the sympathetic chain ganglia. The effect is similar to that described in neonatal rats (Angeletti, Levi-Montalcini and Caramia, 1972; Klein and Torres, 1978; Klein and McKenzie, 1980). The mechanism of action of guanethidine is unknown, but 


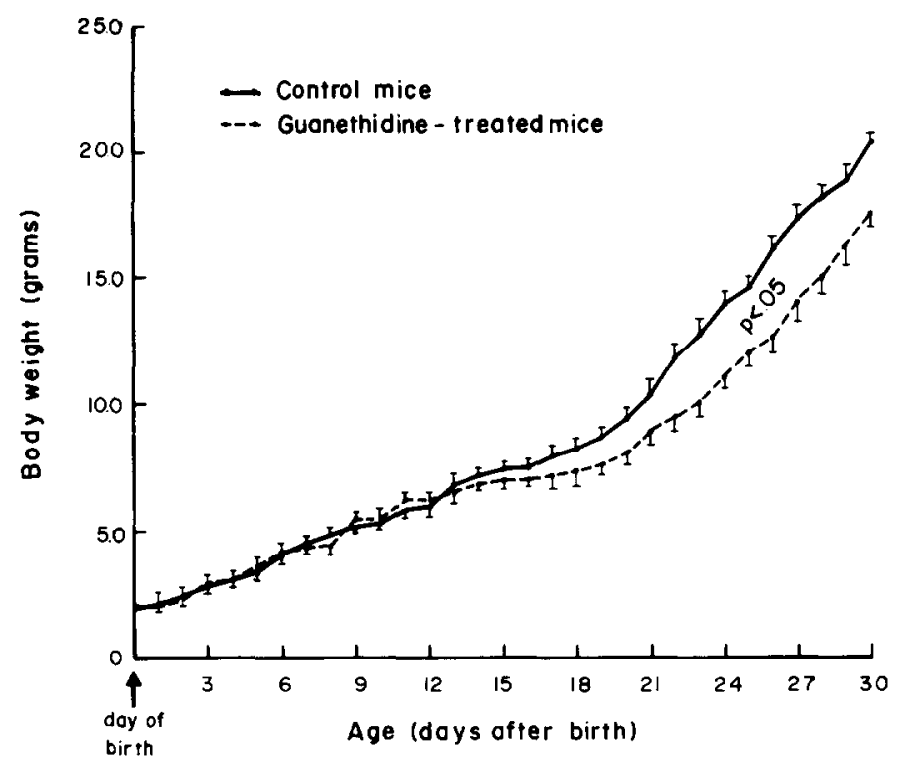

Fig. 1. The effects of guanethidine on growth (body wt) of rats. Slopes of lines differ, $p<0.05$, with a $t$-test for comparison of slopes (Steel and Torrie, 1960).

is not related to interference in transport and storage of nerve growth factor in sympathetic neurons as occurs with vinblastine and 6-hydroxydopamine treatment (Johnson et al., 1979). Destruction of sympathetic ganglia is believed to occur by direct effect on ganglion cells, as alterations induced by guanethidine treatment resemble those produced by postganglionic axotomy, and develop independently of resection of pre- or post-ganglionic sympathetics (Jensen-Holm and Juul, 1970). Those fibres which remain after guancthidine sympathectomy and those which re-innervate the ganglia (up to $1 \mathrm{yr}$ after treatment) are hypothesized to be cholinergic rather than adrenergic (Evans, Heath and Burnstock, 1979).

The sympathetic nervous system and its related receptors have an important role in regulation of continuously renewing proliferative systems. In the small intestinal epithelium, neural stimulation of sympathetic mesenteric nerves increases jejunal crypt cell mitosis (Tutton, 1975), while chemical- (Tutton and Helme, 1974; Klein and Torres, 1978), surgical- (Tutton and Helme, 1974) or immuno-sympathectomy (Dupont, Biggers and Sprinz, 1965) decreases cellular proliferation in the crypts. Other tissues such as the cornea (Friedenwald and Buschke, 1944) and buccal epithelium (McInnes and Tutton, 1976) are sensitive to adrenoreceptor stimulation and blockade. The sympathetic nervous system also has a role in regulation of growth of nconatal organs undergoing expansion and cellular proliferation as part of the growth process. Parotid gland acinar cell proliferation is slightly altered by sympathectomy (Klein, 1979) while submandibular gland growth, but not acinarcell labelling index is altered by chemical sympathectomy with 6-hydroxydopamine (Barka et al., 1972) or surgical interruption of the sympathectic innervation (Srinavasan and Chang, 1977). In addition, tissue norepinephrine levels appear to be related to mitotic circadian rhythmicity (Wurtman and Axelrod, 1966; Tutton, 1973; Klein and Torres, 1978; Klein, 1980) and hormonal circadian patterns (Benson and Krasovich, 1977) in various tissues.

In light of the above studies, the lack of effect of sympathectomy on cellular proliferation in most compartments of the developing mouse incisor is surprising. Sympathetic nerve endings exist in the pulp in juxtaposition to blood vessels or in association with the odontoblast layer (Avery, Cox and Chiego, 1980)

Table 1. Reduction in number of cell bodies after guanethidine treatment of sympathetic ganglia

\begin{tabular}{lcccc}
\hline & & \multicolumn{3}{c}{ Number of Cell Bodies* } \\
\cline { 3 - 5 } & Age (days) & Control & Guanethidine & $\begin{array}{c}\text { Reduction } \\
(\%)\end{array}$ \\
\hline Superior cervical & 15 & $472 \pm 142$ & $151 \pm 78$ & 68.0 \\
Coeliac & 30 & $538 \pm 107$ & $113 \pm 49$ & 78.9 \\
& 15 & $422 \pm 134$ & $151 \pm 83$ & 64.2 \\
& 30 & $486 \pm 113$ & $91 \pm 58$ & 81.3 \\
\hline
\end{tabular}

* Mean number of perikarya $\pm \mathrm{SD}$ is listed for each experimental group. 
Table 2. Percentage of $\left[{ }^{3} \mathrm{H}\right]$-thymidine labelled cells in the proliferative compartment of the mouse incisor (LI) \pm SEM

\begin{tabular}{|c|c|c|c|c|c|c|c|}
\hline \multirow[b]{2}{*}{$\begin{array}{l}\text { Age-treatment } \\
\text { group }\end{array}$} & \multirow{2}{*}{$\begin{array}{c}\text { Inner } \\
\text { enamel } \\
\text { epithelium }\end{array}$} & \multirow{2}{*}{$\begin{array}{c}\text { Outer } \\
\text { enamel } \\
\text { epithelium }\end{array}$} & \multirow[b]{2}{*}{$\begin{array}{c}\text { Stratum } \\
\text { intermedium }\end{array}$} & \multirow[b]{2}{*}{$\begin{array}{l}\text { Stellate } \\
\text { reticulum }\end{array}$} & \multicolumn{3}{|c|}{ Fibroblasts } \\
\hline & & & & & Odontoblasts & Pulp & $\begin{array}{l}\text { Periodontal } \\
\text { ligament }\end{array}$ \\
\hline $\begin{array}{l}15 \text { day } \\
\text { Control }\end{array}$ & $44.1 \pm 4.8$ & $7.5 \pm 1.9$ & $27.0 \pm 3.1$ & $6.0 \pm 1.3$ & $25.8 \pm 4.5$ & $17.1 \pm 3.2$ & $3.9 \pm 1.3$ \\
\hline $\begin{array}{l}\text { Guanethidine- } \\
\text { sympathectomized }\end{array}$ & $\begin{array}{l}43.1 \pm 3.5 \\
(-2.3 \%)\end{array}$ & $\begin{array}{l}5.9 \pm 1.2 \\
(-21.3 \%)\end{array}$ & $\begin{array}{l}20.7 \pm 2.9 \\
(-23.3 \%)\end{array}$ & $\begin{array}{l}4.1 \pm 1.1 \\
(-31.7 \%)\end{array}$ & $\begin{array}{l}22.5 \pm 5.5 \\
(-12.8)\end{array}$ & $\begin{array}{l}21.3 \pm 2.4 \\
(+24.6 \%)\end{array}$ & $\begin{array}{l}3.0 \pm 0.8 \\
(-23.1 \%)\end{array}$ \\
\hline $\begin{array}{l}30 \text { day } \\
\text { Control }\end{array}$ & $12.2 \pm 3.0 \dagger$ & $3.1 \pm 1.7$ & $7.1 \pm 1.8 \dagger$ & $5.3 \pm 1.6^{*}$ & $8.8 \pm 0.9 \ddagger$ & $13.1 \pm 1.8$ & $1.9 \pm 0.4$ \\
\hline $\begin{array}{l}\text { Guanethidine- } \\
\text { sympathectomized }\end{array}$ & $\begin{array}{l}15.2 \pm 4.0 \\
(+24.6 \%)\end{array}$ & $\begin{array}{l}4.7 \pm 2.1 \\
(+51.6 \%)\end{array}$ & $\begin{array}{l}2.2 \pm 0.3^{*} \\
\left(-69.0^{\circ} \%\right)\end{array}$ & $\begin{array}{l}2.1 \pm 0.5^{*} \\
(-60.4 \%)\end{array}$ & $\begin{array}{l}9.5 \pm 2.4 \\
(+8.0 \%) \pi\end{array}$ & $\begin{array}{l}12.3 \pm 2.0 \\
(-6.1 \%)\end{array}$ & $\begin{array}{l}2.0 \pm 0.7 \\
(+5.3 \% \pi\end{array}$ \\
\hline $\begin{array}{l}\text { Reduction in contro } \\
\text { between } 15 \text { and } \\
30 \text { days }(\%)\end{array}$ & 72.3 & 58.7 & 73.7 & 11.7 & 65.9 & 23.4 & 51.3 \\
\hline $\begin{array}{l}\text { Reduction in } \\
\text { guanethidine- } \\
\text { treated mice } \\
\text { between } 15 \text { and } \\
30 \text { days }(\%)\end{array}$ & 64.7 & 20.3 & 89.4 & 48.8 & 57.8 & 42.3 & 33.3 \\
\hline
\end{tabular}

${ }^{*} p<0.05$ by comparison of control and sympathectomized rats.

$\dagger p<0.001$ by comparison of $15-$ and 30 -day-old control rats.

$\ddagger p<0.01$ by comparison of 15 - and 30-day-old control rats.

$\|, 9$ Numbers in parentheses indicate percentage and directional change from control values in $15-$ and 30-day-old rats, respectively.

and appear to be involved with regulation of formation of reparative dentine (Avery, Cox and Corpon, 1974). However, our study indicates that cellular proliferation in most compartments of the incisor is not regulated by the sympathetic nervous system, or that the incisor is able to adapt to the lack of innervation. In the adult rat incisor, removal of the superior cervical ganglion and a large portion of the sympathetic chain have no effect on eruption rate (Taylor and Butcher, 1951). We found no significant alteration in the labelling index of the inner enamel epithelium after guanethidine treatment. These results are in agreement with those of Taylor and Butcher (1951); inner enamel epithelial cell production and cell proliferation are directly proportional to incisor eruption rate (Michaeli, Weinreb and Zajicek, 1972; Bar-Lev et al., 1976).

The greatest changes we found in labelling index were not between control and sympathectomized mice, but between the two developmental groups at 15 and 30 days. Grewe and Felts (1968) found similar changes in cellular proliferation as the incisors develop, erupt, and form and maintain occlusal contact. Eruption occurs in the mouse between the 9th and 11 th day and occlusion of the incisors begins on the 15 th day after birth (Grewe and Felts, 1968). The development of functional occlusion results in a dramatic decrease in cellular proliferation within all the cellular compartments of the developing mouse incisor as seen here and described by Grewe and Felts. The control values we obtained at 30 days also corroborate previous data obtained on cellular prolifer- ation in the different cellular components of the incisor of 45-day-old mice (Chiego et al., 1981). However, there are differences in absolute labelling index values compared to some studies (Hwang and Tonna, 1965; Grewe and Felts, 1968). Differences in labelling indices between our and other studies may be due to variation in the definition of the proliferative zones of the incisor; these have only become welldefined since the work of Warshawsky and Smith (1974).

The effects of chemical sympathectomy were similar in both 15- and 30-day-old rats with the exception of the stellate reticulum and stratum intermedium which showed significantly decreased labelling indices after guanethidine treatment in the 30-day-old rats. Analysis of cell proliferation in these regions has been limited and has usually combined labelling or mitotic index of the outer enamel epithelium, stellate reticulum, and stratum intermedium (Hwang and Tonna, 1965; Grewe and Felts, 1968). However, Kallenbach (1978) proposed that these three layers of cells function in the regulation of nutrient flow to the ameloblasts. If they do act as a semi-permeable membrane, then it is of paramount importance to separate the three layers, outer enamel epithelium, stellate reticulum and stratum intermedium, to evaluate the role each layer has in the proliferation, secretion, and resorptive zones of the rodent incisor. Because sympathectomy produces vasodilatation of arterial vessels the increased tissue pressure could damage the proliferating cells in the region, resulting in a decrease in the percentage of $\left[{ }^{3} \mathrm{H}\right]$-thymidine-labelled cells. 
Several studies have analyzed the effects of multiple injections of guanethidine on tooth eruption rate. Main and Adams (1966) injected guanethidine $(10-20 \mathrm{mg} / \mathrm{kg})$ daily for 8 days to rabbits and found no effect on eruption rate, measured every $48 \mathrm{~h}$. Moxham (1979) demonstrated short-term changes in the rat incisor eruption rate with $3 \mathrm{mg} / \mathrm{kg}$ guanethidine; there was a decrease in eruption rate for $2 \mathrm{~h}$ followed by a rebound effect to a higher eruption rate at $3 \mathrm{~h}$ and a gradual decline towards control values between 3 and $5 \mathrm{~h}$ after guanethidine injection. According to Moxham, differences in species, route of administration, dosage, and duration of measurements between experiments in different laboratories may account for some of the discrepancies in the data. Our findings can best be compared to those of Main and Adams (1966), who used chronic guanethidine administration and found no alteration of eruption rate during this period. However, the effect and mechanism of action of guanethidine treatment may differ in neonatal and adult rats (Bartolome et al., 1976).

Although cellular proliferation within the continuously erupting rodent incisor appears to be independent of sympathetic innervation, the work of Moxham (1979) on short-term effects of guanethidine indicate that other processes may be influenced by the sympathetic nervous system. Morphological studies using the false-transmitter 5-hydroxydopamine show adrenenergic endings throughout the pulp, especially in association with the blood vessels and the odontoblast layer (Avery et al., 1980). Adrenergic responses are mediated by two main subgroups of adrenoreceptors, $\alpha$ and $\beta$ (Ahlquist, 1948). There is little evidence for a $\beta$-adrenergic system in the pulp, but $\alpha$-adrenergic-blocking drugs such as dihydroergotamine increase blood flow in the pulp (Bender, 1978). Future experiments should be directed to the possible role of adrenoreceptors and sympathetic innervation in secretion because cell division in the progenitive compartments appears to be relatively unaffected by sympathectomy.

Acknowledgements-This study was partially supported by U.S.P.H.S. Research DE-01604 from the National Institute of Dental Research. We acknowledge the gift of guanethidine sulphate from Charles A. Brownley Jr, CIBA-Geigy, Summit, N.J. and the excellent secretarial assistance of Gloria Curtis.

\section{REFERENCES}

Allquist R. P. 1948. A study of adrenotropic receptors. Am. J. Physiol. 153, 586-600.

Angeletti P. U., Levi-Montalcini R. and Caramia F. 1972. Structural and ultrastructural changes in developing sympathetic ganglia induced by guanethidine. Brain Res. 43, 515-525.

Avery J. K., Cox C. F. and Chiego D. J. 1980. Presence and location of adrenergic nerve endings in the dental pulps of mice. Anat. Rec. 198(1), 59-71.

Avery J. K., Cox C. F. and Corpron R. E. 1974. The effects of combined nerve resection and cavity preparation and restoration on response dentine formation in rabbit incisors. Archs oral Biol. 19, 539-548.

Bar-Lev M., Zajicek G., Michaeli Y. and Weinreb M. M 1976. Inner enamel epithelium cell production rates. Cell Tissue Kinet. 9, 413-418.
Barka T., Chang W. W. L. and Noen H. van der. 1972. The effect of 6-hydroxydopamine on rat salivary glands and on their response to isoproterenol. Lab. Invest. 27, 594599.

Bartolome J., Bartolome M., Seidler F. J., Anderson T. R. and Slotkin T. A. 1976. Effects of early postnatal guanethidine administration on adrenal medulla and brain of developing rats. Biochem. Pharmac. 25, 2387-2390.

Bender I. B. 1978. Pulp biology conference: a discussion. $J$. Endodont. 4, 37-52.

Benson B. and Krasovich M. 1977. Circadian rhythm in the number of granulated vesicles in the pinealocytes of mice. Effects of sympathectomy and melatonin. Cell Tissue Res. 184, 499-506.

Bernick S. 1956. The innervation of the teeth and periodontium of the rat. Anat. Rec. 125, 185-206.

Brown G. N., Kupfer S. R. and Darlington C. G. 1961. Effects of inferior alveolar nerve severance on the eruption rate of the mandibular incisor in the 10-day old Wistar albino rat. Oral Surg. 14, 1227-1255.

Butcher E. O. and Taylor A. C. 1951. The effects of denervation and ischemia upon the teeth of the monkey. $J$. dent. Res. 30, 265-275.

Chiego D. J., Klein R. M. and Avery J. K. 1981. Effects of inferior alveolar nerve resection on the proliferative compartments of the mouse incisor. Archs oral Biol. MS 200.

Christensen K. 1940. Sympathetic nerve fibers in the alveolar nerves and nerves of the dental pulp. J. dent. Res. 19, 227-242.

Devoto F. C. H., Arias N. H. and Perrotto B. M. 1966. Growth of rat's lower incisor teeth after unilateral section of alveolar nerve. J. dent. Res. 45, 1078-1082.

Dupont J. R., Biggers D. C. and Sprinz H. 1965. Intestinal renewal and immunosympathectomy. Archs Path. 80, $357-362$

Edwards L. F. and Kitchin P. D. 1938. Does resection of the nerves supplying the mandible affect tooth development? J. dent. Res. 17, 115-124.

Evans B. K., Heath J. W. and Burnstock G. 1979. Reinnervation following guanethidine-induced sympathectomy of adult rats. J. Neurocytol. 8, 381-400.

Friedenwald J. S. and Buschke W. 1944. The effects of excitement of epinephrine and of sympathectomy on the mitotic activity of the corneal epithelium in rats. $A m$. $J$. Physiol. 141, 689-694.

Grewe J. M. and Felts W. J. L. 1968. Influence of occlusion on the cellular activity of mouse mandibular incisors. $J$. dent. Res. 47, 65-69.

Hwang W. S. S. and Tonna E. A. 1965. Autoradiographic analysis of labeling indices and migration rates of cellular component of mouse incisors using tritiated thymidine ( ${ }^{3}$ TDR). J. dent. Res. 44, 42-53.

Isotupa K. and Ronning O. 1977. Changes in the dentition of the guinea pig following total section of the inferior alveolar nerve and vessels. Acta anat. 98, 71-76.

Jensen-Holm J. and Juul P. 1970. The effects of guanethidine, pre- and postganglionic nerve division on the rat superior cervical ganglion: cholinesterases and catecholamines (histochemistry), and histology. Acta pharmac. tox. 28, 283-298

Johnson E. M., Macia R. A., Andres R. Y. and Bradshaw R. A. 1979. The effects of drugs which destroy the sympathetic nervous system on the retrograde transport of nerve growth factor. Brain Res. 171, 461-472.

Kallenbach E. 1978. Fine structure of the stratum intermedium, stellate reticulum, and outer enamel epithelium in the enamel organ of the kitten. J. Anat. 126, 247-260.

King J. D. 1936. Dietary deficiency, nerve lesions, and the dental tissues. J. Physiol. 88, 62-77.

Klein R. M. 1979. Alteration of neonatal rat parotid gland acinar cell proliferation by guanethidine-induced sympathectomy. Cell Tissue Kinet. 12, 411-423. 
Klein R. M. 1980. Analysis of intestinal cell proliferation after guanethidine-induced sympathectomy. III. Effects of chemical sympathectomy on circadian variation in mitotic activity. Cell Tissue Kinet. 13, 153-162.

Klein R. M. and McKenzie J. C. 1980. Pattern of crypt cell proliferation in the pre- and post-closure ileum of the neonatal rat: effects of sympathectomy. Cell Tissue Res. 206, 387-394.

Klein R. M. and Torres J. 1978. Analysis of intestinal cell proliferation after guanethidine-induced sympathectomy. I. stathmokinetic, labelling index, mitotic index, and cellular migration studies. Cell Tissue Res. 195, 239-250.

McInnes W. R. and Tutton P. J. M. 1976. Adrenergic inhibition of cell proliferation in the buccal epithelium of rat. Virchows Arch B. Cell Path. 21, 341-348.

Main J. H. P. and Adams D. 1966. Experiments on the rat incisor into the cellular proliferation and blood pressure theories of tooth eruption. Archs oral Biol. 11, 163-178.

Michaeli Y., Weinreb M. M. and Zajicek G. 1972. Role of attrition and occlusal contact in the physiology of rat incisors: V. Life cycle of inner enamel epithelial cells at various rates of eruption. J. dent. Kes. 51, 960-963.

Miller B. G. 1957. Investigations of the influence of vascularity and innervation on tooth resorption and eruption. J. dent. Res. 36, 669-676.

Moxham B. J. 1979. The effects of some vaso-active drugs on the eruption of the rabbit mandibular incisor. Archs oral Biol. 24, 681-688.

Rehak J. R. 1963. Course and resection of the inferior alvelar nerve in the albino rat. $J$. dent. Res. 42, 1159-1168.

Ridehalgh E. and Stewart D. 1938. The course of the incisor branch of the inferior dental nerve in rodents and some observations on the nerve supply of the pulp. $J$. Anat. 72, 416-421.

Ronning O. and Isotupa K. 1973. Changes in the dentition of the guinea pig following partial section of the inferior alveolar nerve. Archs oral Biol. 18, 1050-1062.

Srinavasan R. and Chang W. W. L. 1977. Effect of neonatal sympathectomy on the postnatal differentiation of the submandibular gland of the rat. Cell Tissue Res. 180 , 99-109.

Steel R. G. D. and Torrie J. H. 1960. Principles and Procedures of Statistics, p. 173. McGraw-Hill, New York.

Taylor A. C. and Butcher E. O. 1951. The regulation of eruption rate in the incisor teeth of the white rat. J. exp. Zool. 117, 165-188.

Tutton P. J. M. 1973. Variations in crypt cell cycle time and mitotic time in the small intestine of the rat. Virchows Arch. B Cell Path. 13, 68-78.

Tutton P. J. M. 1975. Neural stimulation of mitotic activity in the crypts of lieberkuhn in rat jejunum. Cell Tissue Kinet. 8, 259-266.

Tutton P. J. M. and Helme R. D. 1974. The influence of adrenoreceptor activity on crypt cell proliferation in the rat jejunum. Cell Tissue Kinet. 7, 125-136.

Vieyra R. M. C. 1927. Dental modifications after expiration of the superior cervical ganglion of the sympathetic. C.r. Séanc. Soc. Biol. 97, 1253-1254.

Warshawsky H. and Smith C. E. 1974. Morphological classification of rat incisor ameloblasts. Anat. Rec. 179 423-466.

Wurtman R. J. and Axelrod J. 1966. A 24-hour rhythm in the content of norepinephrine in the pineal and salivary glands of the rat. Life Sciences 5, 665-669.

Plate 1.

Fig. 2. Sections of superior cervical ganglia from 30-day-old mice. (A) Controls $\times 400$ (B) Sympathectomized rats, arrows indicate neuronophagia in remaining perikarya. Note the large amount of connective tissue (c.t.) and fibroblast infiltration. Haematoxylin and eosin. $\times 400$ 


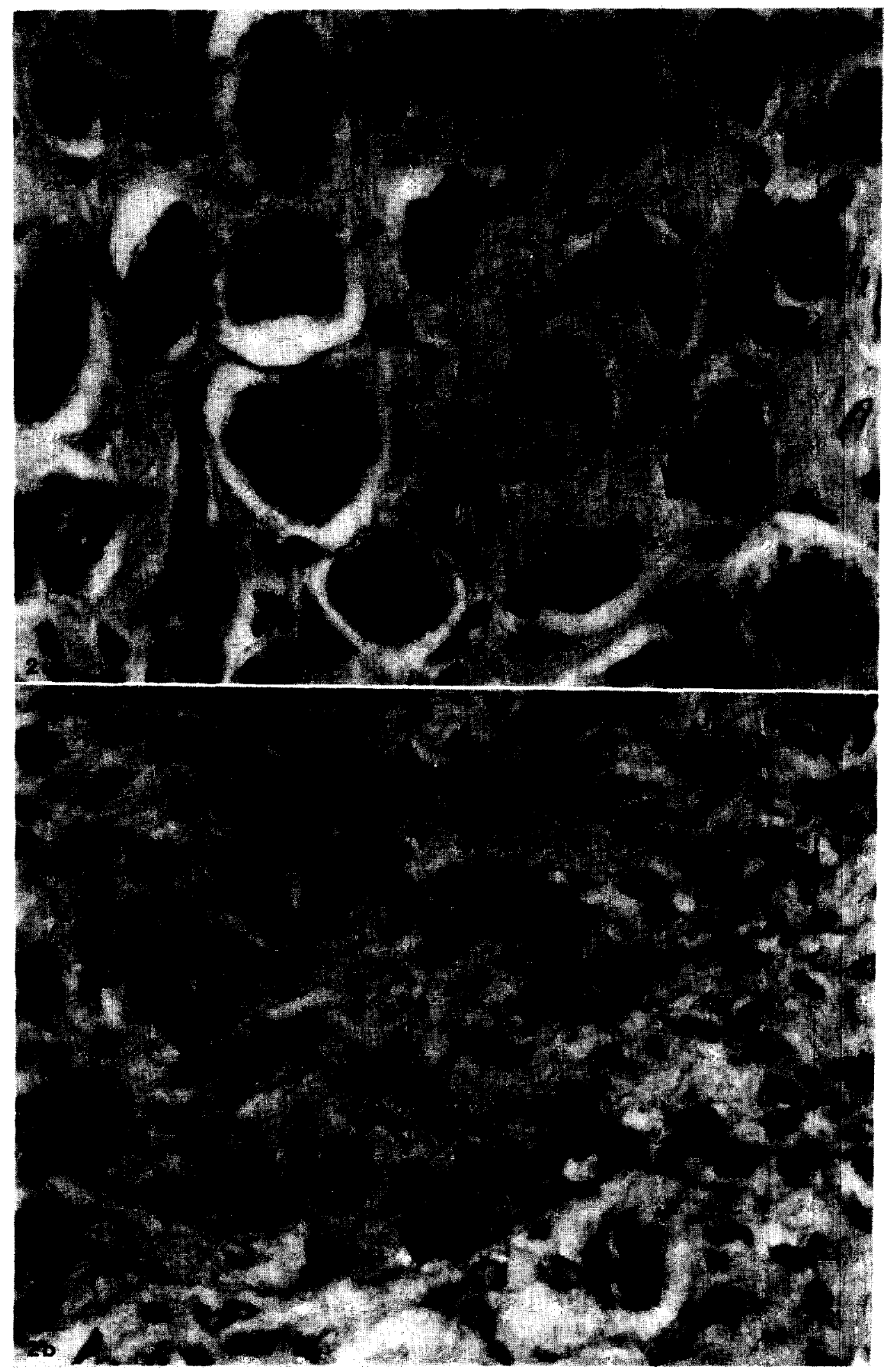

Plate 1. 